\title{
Paper
}

\section{Differences between critical moments for clients, coaches, and sponsors of coaching}

\author{
Erik de Haan \&t Christiane Nieß
}

\begin{abstract}
Objectives: Previous studies on the effectiveness of coaching have focused on positive outcomes that clients, coaches and organisational colleagues attribute to engaging in coaching overall. In this study descriptions of critical moments of coaching as experienced by executive coaching clients, their coaches and their sponsors are analysed and compared, to find out more about how coaching conversations are experienced. In this sense the objective of this research was to understand more about 'sub-outcomes' of coaching: minioutcomes as they arise within the process and as a result of the coaching process.

Design: We extend previous studies in two ways. First, we take a process-oriented, qualitative approach by investigating which events are regarded as critical by clients and coaches within their coaching contracts to date. Second, we consider the perspective of sponsors of coaching who refer to the same coaching assignments as clients and coaches have done.
\end{abstract}

Methods: One-hundred-and-seventy-seven critical-moment descriptions were collected (49 from clients, 49 from coaches and 79 from sponsors of coaching), of which 147 could be matched between coach, client and sponsor working on the same assignment. They are coded with an existing and a new coding scheme and analysed with reference to a larger dataset comprising 555 critical moment descriptions from executive coaching assignments.

Results: Our results suggest that clients and coaches are considerably more aligned in what they regard as critical in their coaching assignments when compared to their alignment with sponsors' views. Whilst clients and coaches mainly refer to moments of new insight and attitudinal change as critical, sponsors underline changes in the clients' behaviour, such as their communication or interpersonal skills.

Conclusions: Alongside earlier studies we have found further indications that clients and coaches conducting normal coaching conversations seem to identify critical moments to a large extent with new learning, perspectives and insight, and they pick the same moments well above chance rates. At the same time, organisational sponsors of coaching seem to prioritise more new actions and changes initiated by coaching clients.

Keywords: executive coaching; critical moments; sponsors of coaching; effectiveness; change; qualitative data.

A LTHOUGH THE TERM executive coaching refers to a diverse range of interventions relying on different paradigms and methodologies, most researchers and practitioners would probably agree that clients of coaching enter the process with learning and development goals, to increase their performance within their organisation, or to reflect upon their own behaviour (De Haan \& Burger, 2005; Downey, 1999; Parsloe \& Wray, 2000; Zeus \& Skiffington, 2002). Most professionals would also agree that coaching is an organisational intervention, designed to benefit an organisation through working with a single indi- vidual (Smither et al., 2003). When clients are asked to evaluate coaching outcomes, they have been found to report higher goal attainment (Grant, 2003), greater self-efficacy (e.g. Baron \& Morin, 2010; Evers, Brouwers \& Tomic, 2006), improved social skills (Spence \& Grant, 2005; Wasylyshyn, 2003), and better team performance (SueChan \& Latham, 2004) in response to coaching interventions. Although some of the coaching outcome studies have used feedback data from peers and managers (Peterson, 1993; Smither et al., 2003; Thach, 2002), what remains largely unexplored is the question of whether and how those 
positive outcomes are also visible to others in the organisation. With organisations spending billions of dollars on coaching interventions globally (Sherman \& Freas, 2004), we need research that establishes whether those investments not just pay off for the client of coaching, but particularly for others whom the client interacts with at work. The present study, therefore, aims to extend previous research by examining the coaching process not only from the perspective of clients and coaches, but also from that of their sponsors in the organisation, who were the clients' direct line managers, partners or HR directors.

Making use of a qualitative methodology, we first aim to replicate existing findings on the critical moments of change that clients and their coaches attribute to their coaching assignments (De Haan, 2008a, 2008b; Day et al., 2008). Secondly, we build on those previous studies by including critical moments that organisational sponsors notice in response to those same coaching assignments. For this purpose we are imagining that in executive coaching there are two processes running concurrently: the coaching process with all its twists and turns, and indeed with critical moments as observed by the two partners; and the organisational processes where coachees collaborate with and work towards requirements of their colleagues, clients, and sponsors. In this research we are comparing the critical moments in this second process to the critical moments from within the coaching process. Our coding of such qualitative data will allow us to identify and quantify similarities and differences in clients', coaches', and sponsors' perceptions of critical moments both within and as a consequence of executive coaching conversations.

\section{Clients' and coaches' critical moments in coaching}

Despite the popularity of coaching interventions in organisations (Sherman \& Freas, 2004), rigorous empirical studies on the outcomes of coaching are rather scarce. The research that has been conducted has generally focused on the clients' and partly on the coaches' perspectives concerning the beneficial outcomes that coaching entails (De Haan \& Duckworth, 2013). Although we recognise the value of such quantitative outcome studies, we start with more qualitative data in this study. By analysing the qualitative data rigorously we aim to shed more light on the question of what happens within the coaching process, in other words we focus more on sub-outcomes than on overall outcomes. Rice and Greenberg (1984) define sub-outcomes as outcomes achieved within the process, from moment to moment, as distinct from outcomes which are generally the result of the process, that is, which can be measured after completing the full coaching assignment.

Several previous research projects have already investigated critical moments in coaching assignments for clients and coaches. More specifically, they have asked clients and coaches the following question: 'Describe briefly one critical moment (an exciting, tense, or significant moment) with your coach/ client. Think about what was critical in the coaching journey, or a moment when you did not quite know what to do. 'Study participants were inexperienced coaches (De Haan, 2008a), experienced coaches (De Haan, 2008b; Day et al., 2008), coaching clients (De Haan et al., 2010a), dyads of coaches and clients that were interviewed directly after their sessions together (De Haan et al., 2010b), and, in a case study, a single dyad of client and coach (De Haan \& Nieß, 2012). Collecting such descriptions of what had been found significant, tense, anxietyprovoking, exciting or pivotal in some way, confirmed that such descriptions of 'critical moments' tend to refer to mayor events in the coaching relationship and can therefore be defined as 'sub-outcomes' of that relationship: important outcomes or events on a moment-by-moment or session-by-session basis (Rice \& Greenberg, 1984). 
Table 1: Critical moments coding scheme as found in De Haan et al. (2010b) and used for this dataset as well as all earlier datasets of descriptions of critical moments in coaching.

\begin{tabular}{|c|l|}
\hline $\begin{array}{c}\text { Code } \\
\text { number }\end{array}$ & Short description of the code \\
\hline 1 & $\begin{array}{l}\text { A moment of learning: new insight. } \\
\text { A moment in which new insight was created for coach and - particularly - client. }\end{array}$ \\
\hline 2 & $\begin{array}{l}\text { A moment of learning: new connections or perspectives. } \\
\text { A moment of working through, reflecting, changing perspective and/or making sense } \\
\text { of existing material. }\end{array}$ \\
\hline 3 & A change in the relationship in the moment (positive). \\
\hline 4 & A change in the relationship in the moment (negative). \\
\hline 5 & $\begin{array}{l}\text { Significance in doing in the moment (coach-led). } \\
\text { Applying oneself to a unique scripted process such as drawing, visualisation, role-play, } \\
\text { GROW, ... }\end{array}$ \\
\hline 6 & $\begin{array}{l}\text { Significance in doing in the moment (client-led). } \\
\text { Doing something relevant: organising future sessions, negotiating the session, } \\
\text { taking away action points, making notes.. }\end{array}$ \\
\hline 7 & $\begin{array}{l}\text { Significant emotional experience in the moment: joy (client). } \\
\text { Heightened positive emotion. }\end{array}$ \\
\hline $\mathbf{8}$ & $\begin{array}{l}\text { Significant emotional experience in the moment: joy (coach). } \\
\text { Heightened positive emotion. }\end{array}$ \\
\hline $\mathbf{9}$ & $\begin{array}{l}\text { Significant emotional experience in the moment: anxiety (client). } \\
\text { Heightened negative emotion. }\end{array}$ \\
\hline 10 & $\begin{array}{l}\text { Significant emotional experience in the moment: anxiety (coach). } \\
\text { Heightened negative emotion. }\end{array}$ \\
\hline 11 & $\begin{array}{l}\text { Significance in being in the moment: doubt (client). } \\
\text { Fundamental not-knowing, often a starting point for reflection. }\end{array}$ \\
\hline 12 & $\begin{array}{l}\text { Significance in being in the moment: doubt (coach). } \\
\text { Fundamental not-knowing, often a starting point for reflection. }\end{array}$ \\
\hline
\end{tabular}

The critical moment descriptions collected in those studies were coded by independent coders using the coding scheme displayed in Table 1, which is described in more detail in De Haan et al. (2010b). Broadly, the coding scheme refers to four categories:

1. Moments of learning (code 1 'New insight' and code 2 'New connection/ perspective');

2. Moments of relational change in the coaching relationship (code 3 'Positive change in the relationship' and code 4 'Negative change in the relationship');
3. Moments of significant action (code 5 'Significance in doing in the moment, coach-led' and code 6 'Significance in doing in the moment, client-led'); and

4. Moments of significant emotional experience (code 7 'Joy, client', code 8 'Joy, coach', code 9 'Anxiety, client', code 10 'Anxiety, coach', code 11 'Doubt, client', and code 12 'Doubt, coach').

The main findings of those previous studies into critical moments of coaching suggest very broadly that while inexperienced coaches express mainly their own doubts as critical moments (De Haan, 2008a), more 
experienced coaches tend to refer to critical moments as sources of anxiety (De Haan et al., 2008b). It is important to note, however, that those coaches were asked for a critical moment with one of their clients, which they could well have interpreted as the most significant moment of their whole portfolio of work. It is, therefore, not surprising that these two groups of participants are biased towards reporting particularly dramatic and emotional moments. When on the other hand clients of coaching were asked for their critical moments of coaching (with the help of the same question above), they instead reported moments of new realisations and insights as particularly critical. Similar results are obtained when dyads of coaches and clients were interviewed independently after a joint coaching session: both parties had a tendency to report new realisations and insights as most critical to the session, and they were in substantial agreement in terms of which moments they selected as being critical in the session they had just completed.

These are important findings and worth testing with a new and wider dataset. The finding that clients are frequently referring to new realisations and insight in their critical-moment descriptions in combination with the fact that they are mostly selecting positive experiences of coaching (De Haan et al., 2010a), may indicate that coaching clients are particularly helped by acquiring new insight and learning. In other words it is possible that on a within-session, moment-bymoment level clients prefer to be served by insight-focused interventions and less by the other three main contributions in executive coaching: problem-focused, person-focused and solution-focused approaches (De Haan \& Burger, 2005). It is important, however, to hold such an interpretation of the earlier findings lightly, because growing client insight will be common to all successful approaches and may, therefore, be one of many 'common factors' in professional coaching approaches. Nevertheless, our growing understanding of how clients describe their most critical moments in the coaching relationship may inform extensive debates in the coaching literature around which method or approach to offer to clients. Since the present study looks into critical-moment descriptions each from a single coaching assignment (rather than taken from a whole portfolio of client work), we would expect to replicate this; more specifically, we suggest:

Hypothesis 1: Clients and coaches mostly refer to moments of insight and learning (Codes 1 and 2 in Table 1) in their criticalmoment descriptions of coaching.

\section{Sponsors' critical moments in coaching}

Whilst rigorous studies concerning the outcomes of coaching interventions from the perspective of clients and coaches are limited to less than 20 (De Haan \& Duckworth, 2013), even fewer studies have investigated whether sponsors notice any positive outcomes that they attribute to the effectiveness of coaching. Nevertheless, preliminary evidence suggests that the beneficial effects of executive coaching are also visible to others in the organisation. Studies which estimate the changes caused by executive coaching in terms of $360^{\circ}$ feedback show that managers who worked with an executive coach receive better evaluations on the second $360^{\circ}$ feedback instrument compared to those who did not work with an executive coach (Smither et al., 2003). Similarly, Thach (2002) found that leaders who were coached for an average of six months received more favourable evaluations through $360^{\circ}$ feedback. Managers and HR partners of coaching clients have been found to report more effective leadership behaviours and better interpersonal skills among participants of a commissioned coaching programme (Wasylyshyn, Gronsky \& Haas, 2006). Olivero, Bane and Kopelman (1997) found that managers who participated in a management development programme with additional coaching received higher ratings of productivity (an 88 per cent increase) compared to managers who 
participated in the management development programme alone (only a 22 per cent increase in productivity).

In sum, there are a few empirical studies which suggest that coaching interventions provide some benefits that are also visible to others in the organisation. The second aim of the present study is to extend this line of research by inquiring more deeply into the experience of line managers and sponsors of coaching clients. More specifically, we aim to identify critical moments for sponsors of coaching and to compare triads of clients, coaches, and sponsors in terms of what critical moments they notice in shared coaching assignments. To the best of our knowledge, only two published studies so far have also included clients', coaches', and sponsors' perceptions of coaching outcomes separately, albeit that in the second study they did not necessarily stem from the same assignments. Peterson (1993) studied $N=370$ leaders from various organisations at three points in time (pre-coaching, post-coaching, and follow-up) with outcome defined by their own coaching objectives and five standard 'control' items, rated by at least themselves, their manager and their coach (multi-source ratings). The coaching programme was intensive and long-term, with typically $50+$ hours of individual coaching with a professional coach over at least a year. Peterson found that clients, on average, achieved significant improvement on all measures of outcome related to coaching objectives (effect sizes $d>1.5$ ). Schlosser et al. (2006) invited triads of clients, coaches, and the clients' managers to report outcomes they attributed to coaching engagements. These participants were asked to select from a list of 25 outcomes the ones that they believed had improved as a result of the coaching engagement. While only $N=14$ managers responded to the authors' request, results indicated that all three groups (clients, coaches, and managers) regarded employee 'engagement' and 'promotability' as the main outcomes of coaching. Managers, however, rated the effectiveness of coaching significantly lower than clients and coaches did.

The present study extends these quantitative approaches by looking at the 'suboutcome' level (Rice \& Greenberg, 1984) for the first time, on the basis of critical-moment descriptions of triads of clients, coaches, and sponsors working together on the same coaching assignment. While we hypothesised that clients and coaches would refer primarily to moments of new insight and learning (codes 1 and 2; see Hypothesis 1), we would argue that such moments of new insight or realisation will be less relevant for the sponsors of those assignments who are only indirectly involved (or only involved directly at the contracting and review stages). For this reason we suggest that sponsors mainly report critical moments which refer to more readily observable moments of change (codes 3 and 4) and to new actions taken by clients (code 6). If this is confirmed we would have some preliminary evidence for sponsors operating more from a 'problem-focused' understanding of executive coaching (De Haan \& Burger, 2005).

Hypothesis 2: Sponsors mostly refer to moments of change in the relationship and significant action taken by the client (codes 3,4 , and 6 ) as critical ones.

The coding scheme which Hypotheses 1 and 2 refer to (see Table 1) was originally developed inductively for classifying many hundreds of clients' and coaches' critical moments of executive coaching. Several codes, therefore, refer to critical moments that are likely to arise within coaching sessions which may be less observable for sponsors of coaching, such as the codes referring to emotional states of coaches and clients (codes 7 through 12). Although we expect these codes of the earlier scheme to be less relevant here, we have chosen to retain the scheme as a whole as a first coding system, to allow a direct comparison with the earlier studies.

However, we also felt the need for a second more tailor-made coding scheme which could test this particular hypothesis. 
Figure 1: Second critical moments coding scheme based on Schein's (1985) 'onion' model.

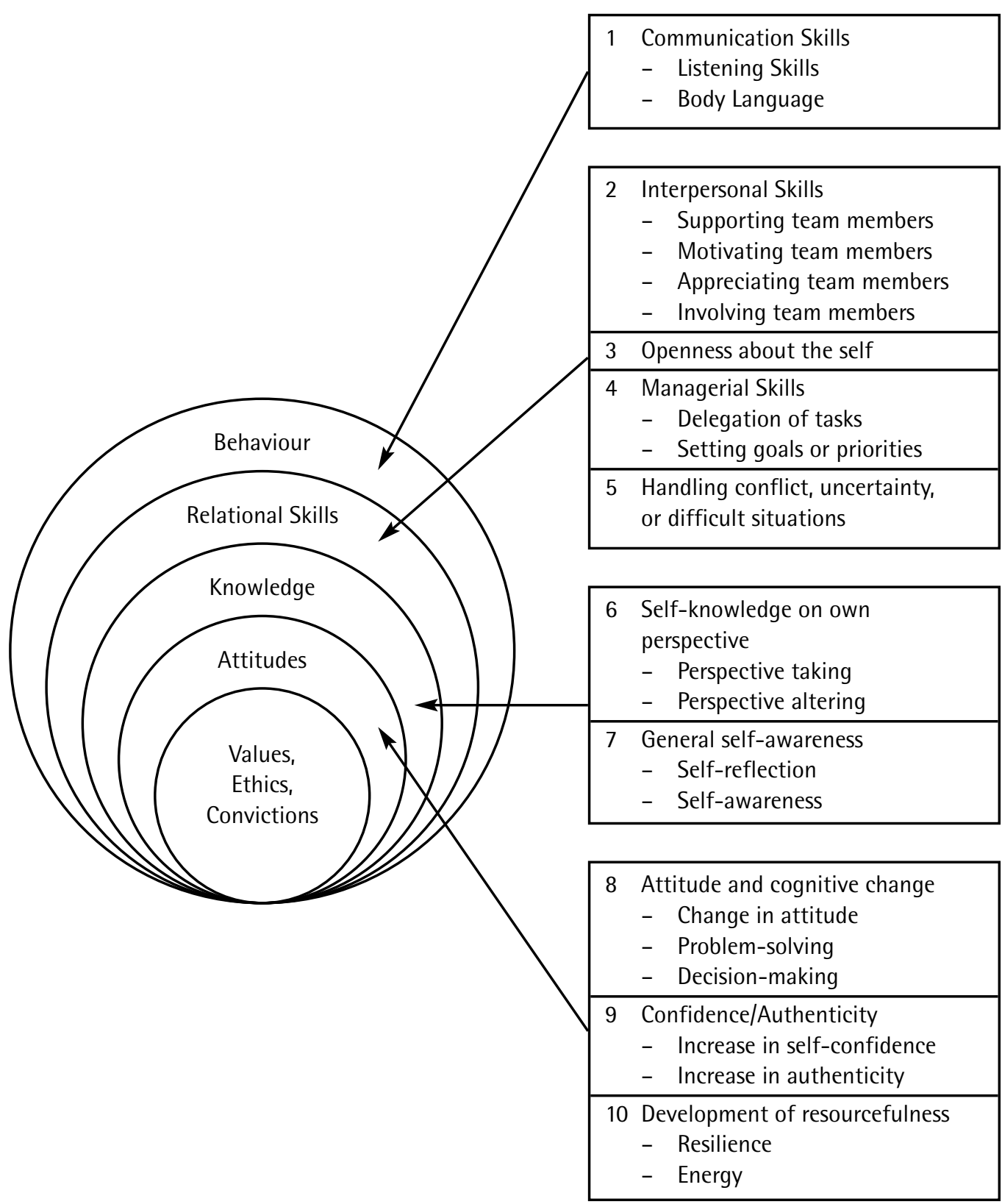

11 Overall change, not specified 
For this reason we adopted a grounded theory approach (Glaser, 1992; Strauss \& Corbin, 1990) to develop a second coding scheme. The grounded-theory approach made use of 41 sponsors' critical-moment descriptions collected at an earlier date (De Haan \& Nieß, 2011). In this inductive way we arrived at another scheme for classifying critical moments of change particularly from the sponsor perspective but usable for all three parties (clients, coaches, and sponsors). We noticed that our scheme turned out similar to Schein's (1985) conceptualisation of the 'onion' of organisational culture. This coding scheme, which is depicted in Figure 1, suggests that while 'outer layers' such as changes in behaviour and communication of coaching are visible to outsiders, 'inner layers' refer to invisible learning or personal change in, for example, attitudes and knowledge. Whilst clients and coaches directly involved in the coaching assignment may thus notice more of the inner levels of the 'onion' model, those inner layers may be less visible to sponsors of coaching. If coding would confirm that sponsors are more occupied with the 'outer layers' of the model, this would give support to the idea that sponsors describe their critical moments more from a 'problem-focused' perspective and less from an 'insight-focused' perspective (see De Haan \& Burger, 2005), which we know has been more the perspective of clients and coaches in regular coaching sessions (De Haan et al., 2010b). We therefore propose:

Hypothesis 3: Sponsors refer significantly more than others to moments of communication or change that are visible on the outer layers of the 'onion' model (codes 1, 2, 3, 4, and 5), as critical ones.

\section{Congruence between clients, coaches, and sponsors}

Hypotheses 1, 2, and 3 are concerned with the nature of the moments that clients, coaches, and sponsors refer to as critical with regard to the shared endeavour of the executive coaching work. What, however, remains unexplored so far is the extent to which those three parties actually refer to the same moments as being critical to them. More particularly, we were interested in finding out how often triplets of clients, coaches, and sponsors refer to the same moment of change that they notice during or as a result of coaching. This would be important as another way to understand the level of agreement between various participants in the coaching assignment, and also as a way to study the 'Rashomon conjecture' proposed and much debated by psychotherapists (Mintz et al., 1973; Weiss, Rabinowitz \& Spiro, 1996).

Previous research has consistently shown that clients and coaches refer to the same moments as critical significantly above chance level, and thus that there is not much of a 'Rashomon effect' in executive coaching, which would be the case when participants in a coaching conversation leave the session with different, incommensurable accounts of their experience together (based on Kurosawa's movie Rashomon where a single event is recounted very differently from four different perspectives). De Haan et al. (2010b) showed that in a client-coach direct comparison study, clients and coaches referred to the same moment in 53 per cent of the descriptions, whilst in a longitudinal investigation where client and coach wrote down their critical moments after each coaching session they referred to the same moment in 47 per cent of the descriptions (De Haan \& Nieß, 2012). Not only did clients and coaches refer to the same incidents at a frequency much higher than chance but they also tended to agree in their descriptions of their critical moments (De Haan et al., 2010b), thereby disconfirming the Rashomon conjecture.

In those two studies, clients and coaches were asked for their critical moments straight after shared coaching sessions, while participants in the present study referred to one coaching assignment consisting of many sessions and they did not normally answer straight after mutual sessions. For this reason we expect numbers of congruence between 
clients and coaches to be smaller than in those two previous studies, yet we suggest that they are still above chance. Since sponsors are not directly involved in the coaching assignments, we expect congruence between clients/coaches and sponsors to be smaller than between clients and coaches.

Hypothesis 4a: The incidence of shared critical moments between clients and coaches, that is, the percentage of cases in which they both refer to the same shared incident, will again be well above chance level (chance level is below one per cent) but also significantly below the level found in earlier studies into a single coaching session (47 to 53 per cent).

Hypothesis 4b: The number of times that sponsors and clients (and also sponsors and coaches) refer to the same moments as being critical is significantly smaller than the number of times that coaches and clients refer to the same critical moments.

\section{Method \\ Sample}

Participants of the present study $(N=177)$ were recruited through two different sources. First, potential sponsors of coaching were approached at a Business School in Great Britain and as part of another study (De Haan \& Wels, 2011), resulting in an initial sample from sponsors of $N=30$. Second, we made use of a large-scale online survey where clients, coaches, and sponsors of coaching who were involved in the same coaching assignment were recruited (De Haan \& Page, 2013), adding $N=49$ clients, $N=49$ coaches, and $N=49$ sponsors of coaching from matching assignments. Sponsors were nominated by the clients as those work colleagues who sponsored their assignment, so they were mainly their line managers, though in some cases they were HR directors or more senior partners in professional services firms. One-hundred-and-thirty sponsors completed the overall research questionnaire (a response rate of around 20 per cent) and 49 of their answers to the open question could be matched with answers by coaches and clients (38 per cent). Participants were drawn from 22 different countries with the help of a wide network of 366 executive coaches who participated in this worldwide large coaching outcome study. Clients and sponsors had an almost equal gender split whilst coaches had an average experience of 13.31 years $(S D=7.19), 67$ per cent were female and 86 per cent were external coaches (with the remainder internal mainly in large public organisations), mostly conducting stand-alone executive coaching assignments.

\section{Materials}

Data for this study were obtained by asking participants whether they have 'experienced something that felt like a 'critical' moment (an exciting, tense, or significant moment) where they noticed a difference and to describe briefly one (or more) such critical moments'; in the case of clients we added 'during coaching'; in the case of coaches we added 'in your work with this client' and in the case of sponsors of coaching we added: 'with your colleague, where you were directly aware of the impact of executive coaching.' We highlighted direct awareness of executive coaching because we are looking for experiences which they somehow relate to the coaching work. We chose the word 'impact' here because it was the most general term we could think of: it could be interpreted as the sponsor wished without limiting the range of their answers. Clients, coaches, and sponsors were thus asked essentially the same question with small modifications, which was also the same as that in all earlier research programmes.

\section{Procedure}

After the 49 clients', 49 coaches', and 79 sponsors' critical moment descriptions had been collected, they were coded three times blindly and independently by four independent coders out of a group of eight coders one of whom being the first author (in the first two of these coding procedures 
critical-moment descriptions were drawn randomly and blindly from all three sources: clients, coaches and sponsors; in the third of the coding the source of the critical-moment description had to be revealed to the coder, by definition):

1. The coding was based on the original coding scheme that has already been used in previous studies (see Table 1). For this first coding, a forced-choice design was employed, forcing the coders to only attach one code to each critical-moment description. We knew from the earlier studies that coders had never asked for more categories. This was replicated in this study, so forced choice with these 12 codes was straightforward.

2. The second way of coding was developed inductively from moments collected from sponsors of coaching, by using a grounded theory approach which on second iteration could be linked with Schein's (1985) 'onion' model (see Figure $1)$. According to this model, organisational culture can be regarded as a metaphorical onion, where visible organisational behaviours are located on the outer layers of the onion, while organisational knowledge refers to less visible, middle layers, and underlying assumptions of the organisation are found in the inner layers. More specifically, 11 codes (see Figure 1) evolved from the sponsors' critical-moment descriptions collected prior to the present study, which naturally fitted into an 'onion' model similar to the one proposed by Schein (1985). The first code, namely changes in communication, such as listening skills or body language, refers to changes in behaviour (first layer of the 'onion' model). Codes 2 through 5 refer to changes in relational skills (second layer of the 'onion' model). They include interpersonal skills (code 2), such as supporting, motivating, appreciating, and involving members of the team, openness about self (code 3), managerial skills (code 4) such as delegating tasks and setting goals and priorities, and handling conflict, uncertainty, or difficult situations (code 5). Codes 6 (self-knowledge, such as perspective-taking and perspectivealtering) and 7 (general self-awareness, and self-reflection) represent the middle layer of the 'onion' model, namely knowledge. Changes in attitude (fourth layer of the 'onion' model) are described by codes 8 through 10 . Code 8 implies changes in attitude and cognitive change, such as problem-solving and decisionmaking, while code nine describes changes in self-confidence and authenticity. Code 10 refers to a development of resourcefulness, such as energy or resilience. Code 11 (overall change, not specified) was developed to fit the descriptions that did not mention a specific change. No code was developed to refer to the core of the 'onion' model (basic assumptions, ethics, and convictions), as none of the critical-moment descriptions referred to changes on that level. For the coding based on this second coding scheme, we again employed a forced-choice design in which coders were asked to only administer one code per critical-moment description - however, in this case the final code is a 'remainder' category (see Figure 1).

3. For the third way of coding, we asked the coders to indicate whether the criticalmoment descriptions from the same assignment (i.e. triplets of client, coach, and sponsor; $N=49$ ) were congruent in that they were referring to the same moment or incident as being critical. More specifically, we asked them to indicate whether they thought there was a correspondence with regards to content between the client and the coach, between the client and the sponsor, between the coach and the sponsor, and between all three critical moment descriptions that came from the same coaching assignment.

To estimate the degree of agreement between coders, Cohen's Kappa was calcu- 
lated for each of the three ways of coding. For the first coding scheme, which includes 12 codes, we found a Cohen's kappa of $\kappa=.240$. For the second coding scheme, using 11 codes, Cohen's kappa was slightly higher at $\kappa=.318$. Finally, the third way of coding (congruence), which has 5 codes, Cohen's kappa was $\kappa=.282$. All codings thus indicate fair agreement between coders (Landis \& Koch, 1977). We averaged the codings by adding up the times each code was assigned to the critical moment descriptions by each coder and dividing through the number of coders and critical moments. This procedure ensured that none of the coders' assessments were lost.

\section{Vignettes of raw data}

In order to help the reader gain a basic understanding of the critical-moment descriptions collected from clients, coaches, and sponsors of coaching, we have chosen a number of short but representative vignettes, which can be found in Table 2 . Those data show the range of critical moments that were mentioned by the participants of this study as well as the range of congruence (which is increasing towards the bottom of Table 2) between the three different parties.

\section{Results}

\section{Clients' and coaches' critical moments in coaching}

Hypothesis 1 suggests that clients and coaches mostly refer to moments of insight or learning (codes 1 and 2) as critical ones. It was tested based on the first coding scheme that was also used in previous studies. Figure 2 displays the proportion of codes assigned to clients', coaches', and sponsors' critical-moment descriptions based on this coding scheme. This graphical representation of the data shows that codes 1 and 2 were indeed used most frequently for coding both clients' and coaches' criticalmoment descriptions. Paired samples $t$-tests were conducted to investigate whether this difference was statistically significant (see
Appendix A). Results indicated that codes 1 and 2 were indeed used significantly more often than all the other codes at $p<.001$, except for code 5 where the difference was not significant. The results were thus mainly supportive of Hypothesis 1.

Results for sponsors' critical moments in coaching Hypothesis 2 states that with respect to the same, original coding scheme, sponsors refer to moments of change and client-led action (codes 3, 4, and 6) as critical ones. Again, Figure 2 includes the graphical representation of the data based on this coding scheme. It shows that sponsors of coaching differ substantially from clients and coaches with respect to their critical-moment descriptions: Clients and coaches seem to be more aligned in their critical-moment descriptions when compared to sponsors (a similar alignment between clients and coaches straight after shared coaching conversations was also found in De Haan et al., 2010b, and De Haan \& Nieß, 2012).

In order to statistically test Hypothesis 2, we again made use of paired sample $t$-tests, comparing the frequencies of codes 3,4 , and 6 to the frequencies of the other codes. Results indicated that codes 3 and 6 were indeed used significantly more often at a $p<.01$ level than any of the other codes (except for code 2, where the difference to code 3 was not significant; see Appendix B). Code 4 was, however, not used at all for coding of sponsors' critical moments, possibly because sponsors only reported positive changes as a result of coaching. The results offer strong but partial support for Hypothesis 2: while code 3 (positive change in the relationship) and code 6 (significance in doing in the moment, client-led) were indeed used significantly more to describe sponsors' critical moments, this was not the case for code 4 (negative change in the relationship).

Based on the second coding scheme grounded in the 'onion' model of organisational change, Hypothesis 3 states that sponsors mainly refer to moments of change that 
Table 2: Vignettes of the critical moment descriptions with in each row data from the same coaching assignment. Towards the bottom of this table one can observe the degree of 'congruence' between the three parties increasing.

\begin{tabular}{|c|c|c|c|}
\hline & Clients' critical moments & Coaches' critical moments & Sponsors' critical moments \\
\hline 1 & $\begin{array}{l}\text { Significant moment when } \\
\text { I realised, through input } \\
\text { from my coach, how a } \\
\text { helping conviction can } \\
\text { improve your confidence } \\
\text { and behaviour. }\end{array}$ & $\begin{array}{l}\text { Challenging was the fact } \\
\text { that I didn't know if I was } \\
\text { the right coach for her. I } \\
\text { didn't feel comfortable [...] }\end{array}$ & $\begin{array}{l}\text { In general during } \\
\text { interaction with other team } \\
\text { members and the client, } \\
\text { where my counselee was } \\
\text { much more open and } \\
\text { engaged in the discussions. }\end{array}$ \\
\hline 2 & $\begin{array}{l}\text { The moment I recognised, } \\
\text { through my coaching, that } \\
\text { I was the one of all my } \\
\text { brothers and sisters who } \\
\text { organised [...] }\end{array}$ & $\begin{array}{l}\text { I experienced a significant } \\
\text { moment when this client } \\
\text { realised that his behaviour } \\
\text { as adult was still influenced } \\
\text { by limiting believes from his } \\
\text { youth [...] }\end{array}$ & $\begin{array}{l}\text { [...] Before the coaching my } \\
\text { colleague usually had a big } \\
\text { problem in dealing with } \\
\text { difficult situations and put } \\
\text { all his energy in defending } \\
\text { the approach of his people. } \\
\text { It was remarkable that he } \\
\text { took his time to listen, ask, } \\
\text { and analyse [...] }\end{array}$ \\
\hline 3 & $\begin{array}{l}\text { Realising that my anxiety in } \\
\text { groups was created by me } \\
\text { most of the time by } \\
\text { negative thought patterns } \\
\text { and hence I also had the } \\
\text { capacity to change that } \\
\text { thinking (and hence the } \\
\text { feelings). }\end{array}$ & $\begin{array}{l}\text { When she tackled a long- } \\
\text { standing area of concern } \\
\text { with her partner and had a } \\
\text { positive outcome [...] }\end{array}$ & $\begin{array}{l}\text { Increased confidence in } \\
\text { conversing at multi } \\
\text { professional meetings where } \\
\text { there are strong dominating } \\
\text { personalities. }\end{array}$ \\
\hline 4 & $\begin{array}{l}\text { There was a session when } \\
\text { the coach let me talk to } \\
\text { myself in a role playing } \\
\text { game. }\end{array}$ & $\begin{array}{l}\text { My client told me about a } \\
\text { clash between her and a } \\
\text { collegue of hers about her } \\
\text { sub-assertive behaviour. } \\
\text { She got emotional about } \\
\text { being unable to gather the } \\
\text { courage to stand up to her } \\
\text { [...] }\end{array}$ & $\begin{array}{l}\text { She has made advantages } \\
\text { especially in situations with } \\
\text { a colleague that can be } \\
\text { quite snappy. Before } \\
\text { coaching, she was swiped } \\
\text { off her feet or intimidated, } \\
\text { after coaching she stands } \\
\text { by her opinion [...] }\end{array}$ \\
\hline 5 & $\begin{array}{l}\text { In one of the sessions I } \\
\text { realised that I had the } \\
\text { know-how in dealing with a } \\
\text { confrontational situation, I } \\
\text { just had to remain calm and } \\
\text { deal with it in a calm } \\
\text { manner [...] }\end{array}$ & $\begin{array}{l}\text { At the end of the second } \\
\text { session I felt a marked shift } \\
\text { in her attitude and } \\
\text { confidence in moving } \\
\text { forward effectively. } \\
\text { She suddenly appeared in } \\
\text { control and not just } \\
\text { reacting emotionally. }\end{array}$ & $\begin{array}{l}\text { My colleague appears to be } \\
\text { more patient with those she } \\
\text { manages and appears to be } \\
\text { more approachable. There } \\
\text { appears to be less conflict } \\
\text { situations in the office [...] }\end{array}$ \\
\hline
\end{tabular}


Figure 2: Proportions of codes assigned to clients', coaches', and sponsors' critical moment descriptions within original first coding scheme.

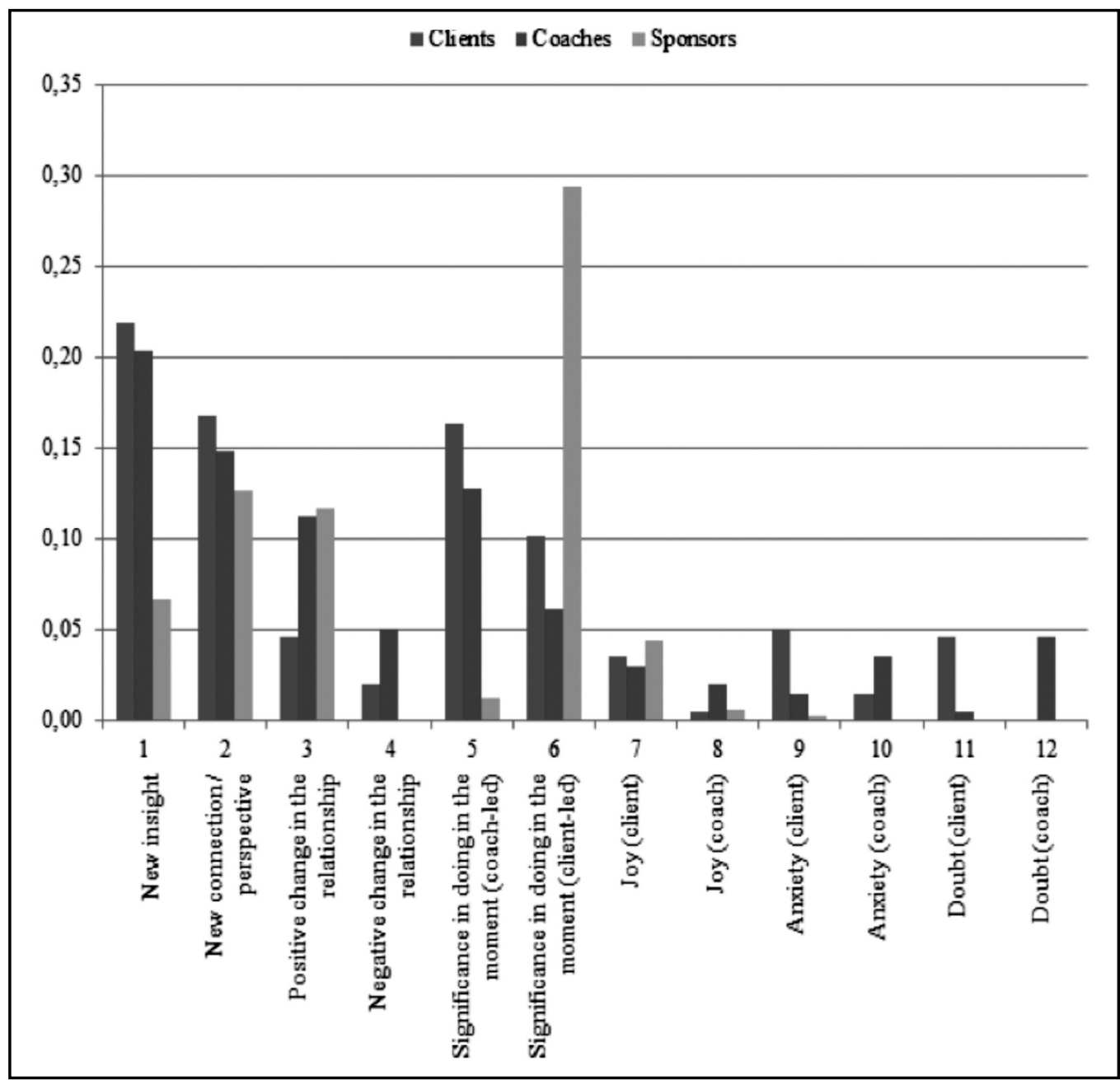

are visible as they are on the outer layers of the client-as-onion model (codes 1, 2, 3, 4, and 5) as critical ones. Figure 3 displays the proportions of codes from the second coding scheme assigned by coders to the critical-moment descriptions for clients, coaches, and sponsors of coaching. The graphical representation of the results suggests that codes 1 (communication skills) and 2 (interpersonal skills) were used very frequently for coding sponsors' criticalmoment descriptions, especially when compared to the ratings for clients' and coaches' critical-moment descriptions. Codes 8 (attitude and cognitive change) and 9 (confidence/authenticity) were, however, also used frequently for coding sponsors' critical-moment descriptions. Paired sample $t$-tests were again conducted to test whether the differences in the frequencies of codes 1 , 2, 3, 4, and 5 in comparison to the other codes were statistically significant. Results (see Appendix C) indicated that code 1 was only used significantly more frequently for coding sponsors' critical moments than code 6 , but not more frequently than any of the 
other codes. Code 2 was used more frequently than codes 6,10 , and 11 , but there was no difference to the other codes. Codes 3 and 4 were not used significantly more frequently than any of the other codes. Code 5 was used significantly more often than code 6 only. In sum, the results suggest that codes 1 (communication skills) and 2 (interpersonal skills) were indeed used more frequently than some of the other codes, offering only limited support for Hypothesis 3 . However, some of the codes on the inner layers of the 'onion' model, such as codes 7 (general self-awareness), 8 (attitude or cognitive change), and 9 (confidence/ authenticity) were not used significantly less frequently for coding sponsors' criticalmoment descriptions.

The results of both coding schemes thus suggest that clients and coaches are more aligned in what they regard as critical moments in their coaching assignments than sponsors are. With respect to the first, original coding scheme, we tested that finding with paired sample $t$-tests and our results indicate that sponsors of coaching reported fewer moments of new insights (code 1) and coach-led significance in doing in the moment (code 5) than clients and coaches did. Instead they reported more critical moments that were coded as clientled significance in doing in the moment (code 6) when compared to both clients and coaches. With respect to the second, newlydeveloped coding scheme, we found that sponsors of coaching referred to significantly more critical moments of communication skills (code 1) than clients, but the difference to coaches was only marginally significant. Sponsors furthermore referred significantly more often to critical moments that were coded as interpersonal skills (code 2) than clients and coaches. Sponsors, however, referred to significantly fewer critical moments that were coded as selfknowledge on own perspective (code 6) or general self-awareness (code 7). Sponsors thus refer to more changes in the outer layers of the 'onion' model (codes 1 and 2), while clients and coaches refer more frequently to changes on the inner layers of the onion (codes 6 and 7).

\section{Results for congruence between clients, coaches, and sponsors}

We were also interested in the degree of congruence between triplets of clients', coaches', and sponsors' critical-moment descriptions, as they were referring to the same coaching assignments. More specifically, we suggest that the degree to which both clients and coaches refer to the same moments as critical is above chance (Hypothesis 4a) and that the degree to which both sponsors and clients refer to the same moments as critical is smaller than the degree to which both coaches and clients refer to the same moments as critical (Hypothesis 4b). A graphical representation of the results pertaining to those two hypotheses can be found in Figure 4. It shows that in almost 40 per cent of the cases there is no congruence between any of the three parties in what moments they refer to as critical ones. Put differently, in almost 40 per cent of the criticalmoment descriptions, none of the coders recognised a congruence. In almost half of the cases (46 per cent), clients and coaches, however, refer to the same critical moments of their coaching assignments. Given that these coaching assignments had lasted for an average of near eight sessions (a median of seven sessions), which would be more than 10 hours of coaching on average, this amounts to a correspondence which was well above chance and offers strong support for Hypothesis 4 a. Figure 4 also shows that correspondence between clients and sponsors (26 per cent) as well as between coaches and sponsors (24 per cent) was considerably smaller, thus offering support for Hypothesis 4b.

However, as this is narrative research we need to be careful with our interpretations: here, we seem to have found congruence between all three parties, and particularly between coaches and clients, a degree of congruence which is clearly above chance. On the other hand, any congruence we 
Figure 3. Proportions of codes assigned to clients', coaches', and sponsors' critical-moment descriptions within second coding scheme based on Schein's (1985) 'onion' model.

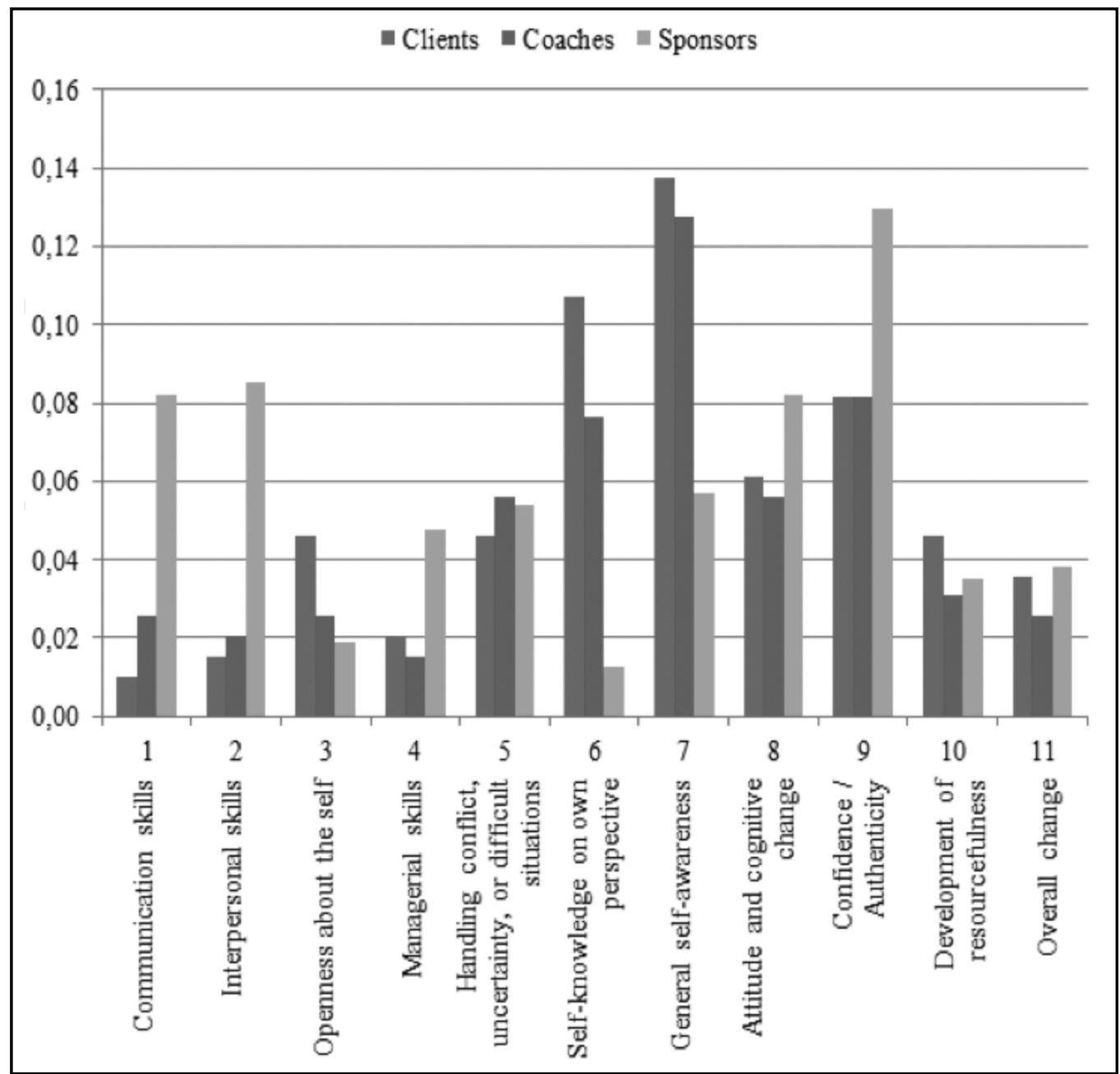

found is not - and can never be - full congruence, because the critical-moment descriptions are by design independent and therefore different. They have only been recognised by coders as belonging to similar instances of the coaching work. Moreover, there is a sample of almost 40 per cent of all critical-moment descriptions remaining where the coders report no congruence across client, coach or sponsor perspectives. We do not know if in those descriptions completely incommensurable narratives were told, or rather narratives which other parties would easily recognise as well, simply because we have no means to test this retrospectively. So despite the surprisingly high agreement in both selection and nature of description of critical moments (compare Figure 2) between clients and coaches, we cannot rule out significant remaining 'Rashomon' phenomena where both parties tell very different stories indeed. 
Figure 4: Congruence between clients, coaches, and sponsors referring to the same coaching assignments.

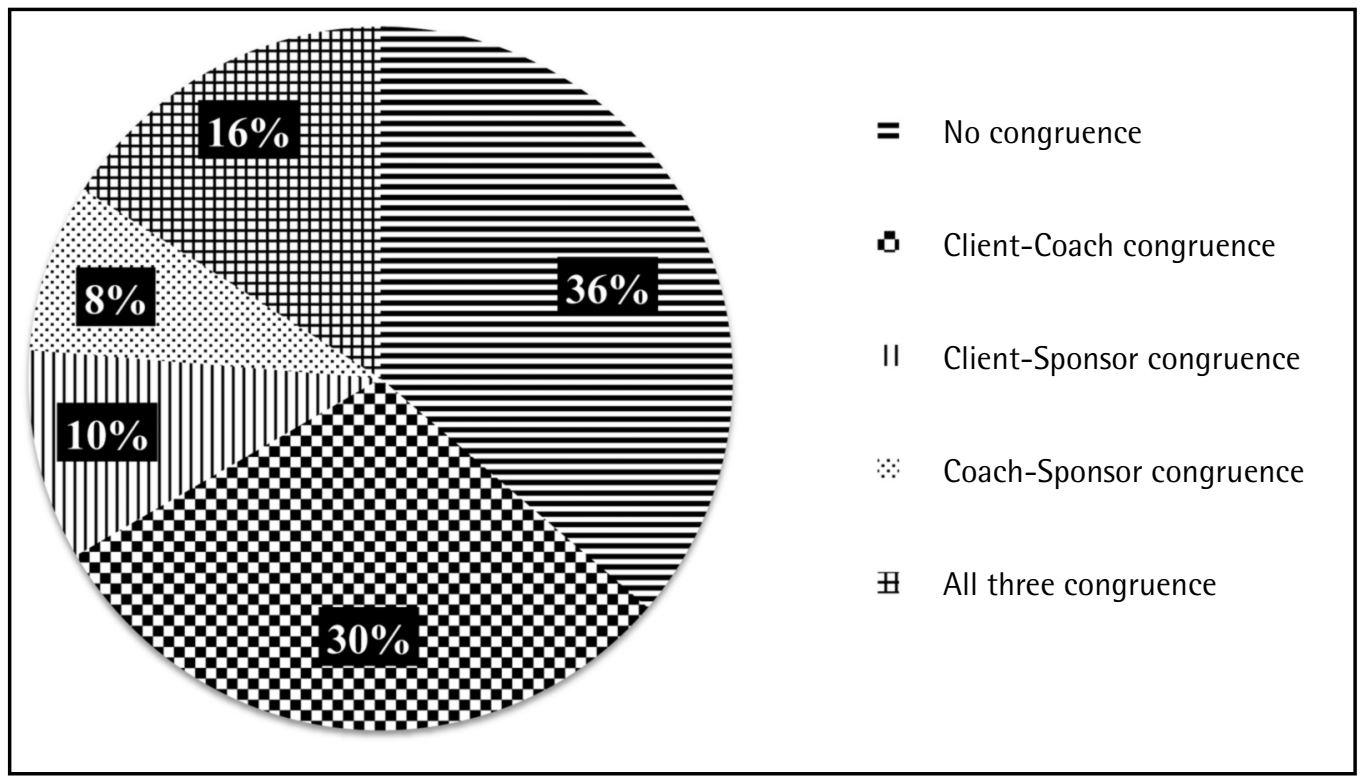

\section{Discussion}

The aim of the present study was to investigate critical moments of coaching for clients, coaches, and sponsors referring to the same coaching assignments. Our results suggest that overall clients and coaches are considerably more aligned in what they regard as critical moments than sponsors are, even when all three parties are referring to the same coaching assignment. More particularly, we find that clients and coaches mostly refer to moments of new realisations and insights as well as coach-led significance in doing in the moment as critical. They also frequently noticed changes on the inner layers of a metaphorical onion (i.e. understanding and self-awareness) and refer to the same moments as critical ones in almost half of their descriptions. Sponsors, on the other hand, mainly notice positive changes in the relationship with the client as well as clientled significance in doing in the moment as critical moments. Overall sponsors have been very positive in their descriptions which explains why there are no codes in 'negative changes in the relationship' (code 4; see
Figure 2). This could be due to self-selection because a significant proportion of sponsors in the large-scale research project chose not to answer this question. Also, the changes in terms of the 'onion' model are noticed more frequently on the outer layers, such as in clients' communication and interpersonal skills. Finally, coaches and clients seem to be much more congruent (a correspondence of 46 per cent) in terms of which moments they selected as being critical, than either sponsors and clients or sponsors and coaches (correspondences of 26 per cent and 24 per cent, respectively).

These findings become more convincing if they are compared directly with the original datasets of earlier studies, as we have done in Figure 5. We can then appreciate that blind coding of all seven datasets of critical-moment descriptions (a total of 555 critical-moment descriptions each coded by at least three coders of which one, AC, coded every dataset) collected from inexperienced coaches, experienced coaches (two datasets), clients of coaching, clients and 
coaches together after a shared session (two datasets), and sponsors of coaching assignments, are actually very distinct:

1. Critical moments from inexperienced coaches over their whole coaching experience are classified as 'doubts of the coach' (code 12) in more than half of cases. The coach's anxieties (code 10) are also prominent.

2. Critical moments from experienced coaches over their whole coaching experience peak at both 'doubts' and 'anxieties' of the coach (codes 10 and 12 in equal measure).

3. Critical moments from coaches and clients straight after sessions contain mainly new insights (code 1) and new perspectives (code 2).

4. Critical moments from sponsors of coaching (this research) are coded as 'significant action led by the client' (code 6) in almost a third of cases.

Compared with those earlier findings the data from the coaches as collected this time (which are visible in Figure 2 and not in Figure 5), are a mixture of the earlier patterns as one would expect. This dataset contains mostly experienced coaches but we have not excluded inexperienced coaches, and is based on assignments that have just started as well as assignments that have gone on for many hours (in fact we could reliably estimate that on average client and coach had already spent more than seven sessions together). In Figure 2 we can see that the coach data in fact contain a significant amount of anxiety and doubt, features we would only expect if either coaches were very inexperienced or if they are reporting the most significant moments of their careers (which was the case in De Haan, 2008a, 2008b; and Day et al., 2008). This may also contribute to the fact that the overlap between client moments and coach moments (46 per cent in this study) is marginally smaller than in the earlier studies (De Haan et al., 2010b, and De Haan \& Nieß, 2012, where this degree of overlap was 53 per cent and 47 per cent, respectively).
We would still consider that the fact that almost half of critical-moment selections overlap between client and coach is remarkable particularly as we know that they had an average of some eight sessions together before answering the questionnaire. Taken together, these findings mean that all earlier conclusions from critical moments in coaching studies that we could test are supported in this study.

The present study extends previous research by also including sponsors' criticalmoment descriptions. Figure 5 embeds the sponsors' critical-moment descriptions obtained in the present study into previous research conducted with clients, coaches and coach-client dyads. The figure shows that more than a quarter of the criticalmoment descriptions from sponsors have been categorised as containing changes in clients' behaviours (code 6), which is some first evidence that organisational sponsors and managers do attribute behavioural changes in their employees to coaching assignments undertaken.

Together with the earlier qualitative research into critical moments in real, contracted, executive-coaching assignments this study offers support for the presence of tangible change within and as a result of coaching conversations (e.g. we could confirm Hypothesis 3). We believe that we now have ample evidence that clients and coaches by and large agree on the kind of momentary changes through coaching, except in or near the presence of significant ruptures in the relationship where coaches report significantly more emotions in the form of anxiety and doubt (De Haan et al., $2010 \mathrm{~b})$. Finally, we have found further evidence that also sponsors can recognise significant change coming out of coaching conversations (Hypotheses 2 and 3). However, sponsors draw attention to a different aspect of these changes, namely the actions that the clients initiate as a result of coaching conversations. At this stage of research we are beginning to see evidence of the organisational experience of coaching 
Figure 5: Comparison of sponsors' critical moments with earlier research findings.

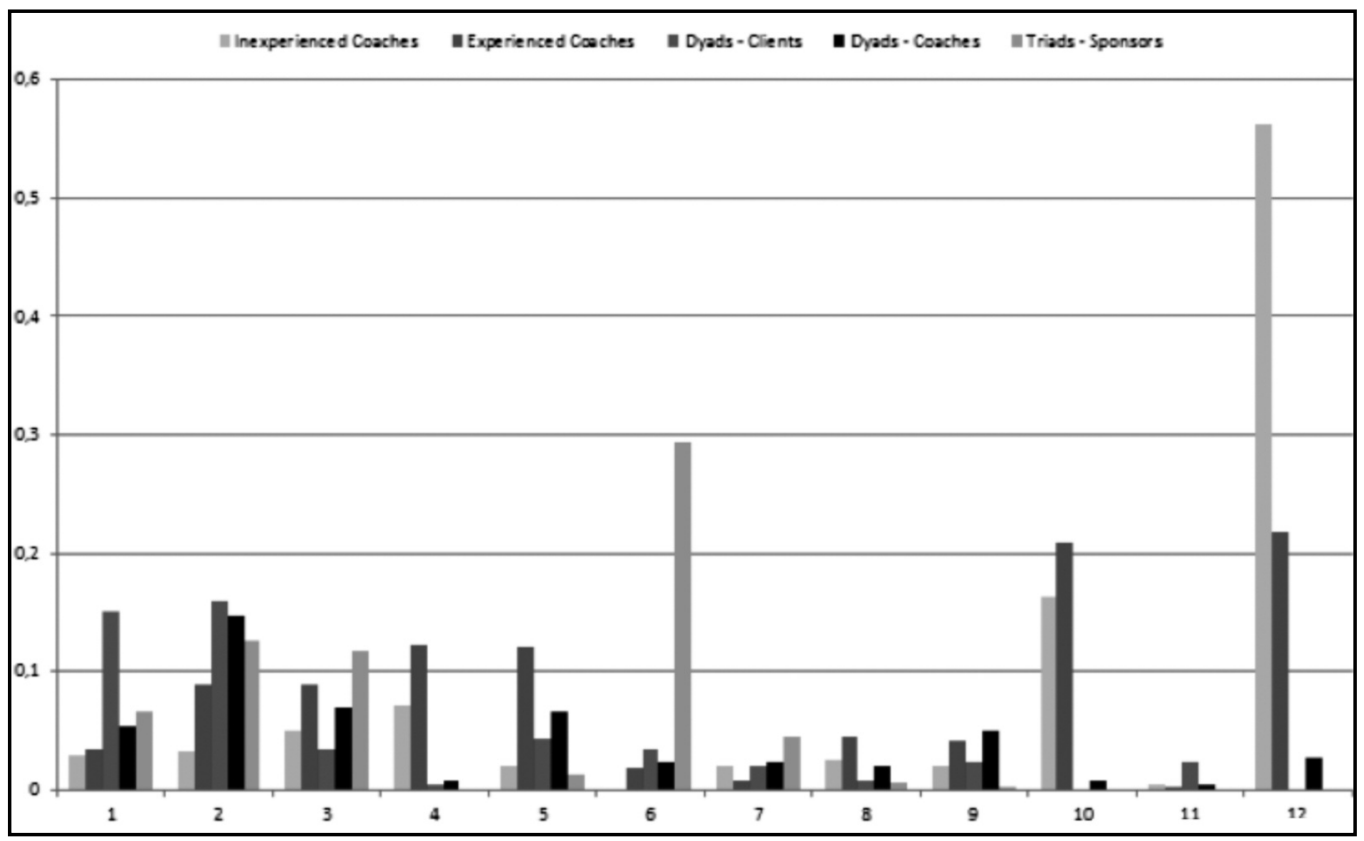

conversations, and we are beginning to see consequences of those conversations through analysing critical moments experienced by third parties. This kind of scrutiny of critical moments in coaching conversations is giving us some idea of the differences in mind-sets engendered by the three roles taken in and around coaching sessions, those of client, coach and sponsor. These differences in mindsets are well described by the 'window on coaching' model put forward by Clutterbuck (1985) and De Haan and Burger (2005):

1. Clients and coaches conducting normal coaching conversations seem to have an 'insight-focused' ideology where significant moments are those of new learning: new perspectives and new insights related to self and coaching objectives and themes;

2. Coaches when in the presence of rare ruptures or dramatic events in coaching conversations seem to have a "personfocused' ideology where the orientation is much more towards highly personal anxieties, emotions and doubts;
3. Organisational sponsors of coaching seem to have more of a 'problem-focused' or 'solution-focused' mindset which is more action-, behaviour- and future-oriented.

It is interesting that within these overall differences sponsors do mention deeper layers of personality, such as self-awareness, attitude, confidence and authenticity (see Figure 3), even as much as the coaches and clients are doing. The sponsors may be more interested in changes in their relationship with their colleagues (Figure 2), they still define those relationships as multi-layered and not just superficially in terms of communication and behaviour (Figure 3).

Knowing more about the ideology of the various partners that come to build the coaching relationship can be extremely helpful. Coaches can adapt their contracting to what the other parties find most critical in this helping relationship - and they can also adapt their style in the presence of misunderstandings and ruptures. All in all communication between the various parties working together in this essentially triangular endeavour can be improved by a deeper 
knowledge of likely default ideologies, such as their orientations towards emotions, problems, solutions, and insights. Finally, we may be discovering how change from executive coaching is being retranslated and refined through the various stakeholders involved: coaches may be focusing a lot on their own anxieties and doubts, yet at the same time translating this sensitivity into new insight for clients (by, for example, free association and making use of countertransference, as in insight-focused approaches - De Haan \& Burger, 2005). Clients may then be able to translate new insight into new behaviour and a changed outlook within their organisations, translating their new learning into observable relational change with their sponsors and other counterparts (adapting to work environments which may be more action- and problem-oriented than coaching conversations), as well as, conversely, retranslating new organisational experiences into requests for new insight from coaching, etc. The substantive and measurable emerging changes from executive coaching conversations that are beginning to come to light in coaching outcome studies (De Haan \& Duckworth, 2013) are well captured by the following words from Mahatma Gandhi: 'Carefully watch your thoughts, for they become your words. Manage and watch your words, for they will become your actions. Consider and judge your actions, for they have become your habits. Acknowledge and watch your habits, for they shall become your values. Understand and embrace your values, for they become your destiny.' It is as if a coaching conversation creates a 'ripple' in the mind which propagates, first between client and coach, and then in the form of new action into and within the organisational context of the coaching client.

\section{Limitations}

Limitations of the present study were

- Firstly, that the sponsor dataset is still quite limited (only 79 sponsor criticalmoment descriptions of which 49 could be matched to both clients' and coaches' descriptions), despite our having access to a very large-scale research programme which has yielded more than 4000 questionnaires. We think that because of their more detached and supervisory role it is harder to collect usable data from organisational sponsors (compare De Haan \& Nieß, 2011). A larger dataset would allow us to dig more deeply into the perceptions that organisational colleagues tend to develop towards coaching clients, in their roles of sponsors of executive coaching.

- Secondly, that the degrees of agreement between coders are still relatively small (Cohen's Kappa around $\kappa=.3$ ). Kappas are similar to those in previous studies and they are probably small because coders are collapsing whole narratives into single code descriptors. In our view both larger datasets and finer coding systems will need to be developed if we really want to understand what makes a difference in coaching conversations, and for each party to those conversations.

- Thirdly, and following from the previous point, coding in narrative research and the social sciences is bound to suffer from considerable overlap between coding categories and from differences in interpretation of the meaning of both the narratives (the critical-moment descriptions) and the coding categories. Such fuzziness around meaning is hard to avoid without losing the richness of the original experiences, but will further degrade agreement between coders.

\section{Further research}

Critical-moment descriptions have convincingly been shown to be a promising area of coaching process research, and we can only hope that more studies will appear in the future so that our understanding of "critical incidents', 'sub-outcomes' or 'momentary changes' in coaching assignments deepens and expands further. In particular, it seems important to explore more deeply the area of (non-)congruence of critical-moments descriptions, by not just collecting descrip- 
tions of critical moments of coaching but also asking clients, coaches and perhaps even sponsors, to which degree they can recognise the narratives of the other parties in the common endeavour. Such research should be able to shine more light on the Rashomon conjecture, the question whether participants in shared sessions develop similar or essentially different narratives of their time spent together.

\section{Acknowledgments}

We would like to thank our Ashridge colleagues Andy Copeland, Stefan Cousquer, Myrna Jelman, Tsheli Lujabe, Niraj Saraf, Charlotte Sills and Dorothee Stoffels for their careful coding of the critical-moments descriptions.

\section{References}

Baron, L. \& Morin, L. (2010). The impact of executive coaching on self-efficacy related to management soft-skills. Leadership $\mathcal{E}$ Organization Development Journal, 31(1), 18-38.

Day, A., De Haan, E., Sills, C., Bertie, C. \& Blass, E. (2008). Coaches' experience of critical moments in the coaching relationship. International Coaching Psychology Review, 3(3), 207-218.

De Haan, E. (2008a). I doubt therefore I coach: Critical moments in coaching practice. Consulting Psychology Journal: Practice and Research, 60(1), 91-105.

De Haan, E. (2008b). I struggle and emerge: Critical moments of experienced coaches. Consulting Psychology Journal: Practice and Research, 60(1), 106-131.

De Haan, E. \& Burger, Y. (2005). Coaching with colleagues. An action guide for one-to-one learning. Hampshire, Great Britain; New York: Palgrave Macmillan.

De Haan, E. \& Duckworth, A. (2013). Signalling a new trend in coaching outcome research. International Coaching Psychology Review, 8(1), 6-20.

De Haan, E. \& Nieß, C. (2011). Change through executive coaching. Training Journal, 7, 66-70.

De Haan, E. \& Nieß, C. (2012). Critical moments in a coaching case study: Illustration of a process research model. Consulting Psychology Journal: Practice and Research, 64(3), 198-224.

De Haan, E. \& Page, N. (2013). Outcome report: Conversations are key to results. Coaching at Work, $8(4), 10-14$.

\section{The Authors}

Dr Erik de Haan is Director of Ashridge Centre for Coaching, Trainee Psychodynamic Psychotherapist and Professor of Organisation Development and Coaching at the VU University of Amsterdam.

Christiane Nieß is based in the Cologne Graduate School in Management, Economics, and Social Sciences, Cologne University, Germany.

\section{Correspondence \\ Erik de Haan}

Email: erik.dehaan@ashridge.org.uk

De Haan, E. \& Wels, I. (2011). De link tussen top, topteams en high performance [Development at the top: An inquiry into personal development at executive-board level]. Management $\mathcal{E}$ Consulting, 4, 44-46.

De Haan, E., Bertie, C., Day, A. \& Sills, C. (2010a). Critical moments of clients of coaching: Towards a 'client model' of executive coaching. Academy of Management Learning and Education, 5(2), 109-128.

De Haan, E., Bertie, C., Day, A. \& Sills, C. (2010b). Critical moments of clients and coaches: A directcomparison study. International Coaching Psychology Review, 5(2), 109-128.

Downey, M. (1999). Effective coaching. London: Orion. Evers, W.J., Brouwers, A. \& Tomic, W. (2006). A quasiexperimental study on management coaching effectiveness. Consulting Psychology Journal: Practice and Research, 58(3), 174-182.

Glaser, B.G. (1992). Basics of grounded theory analysis. Mill Valley, CA: Sociological Press.

Grant, A. (2003). The impact of life coaching on goal attainment, metacognition and mental health. Social Behaviour and Personality, 31(3), 253-264.

Landis, J.R. \& Koch, G.G. (1977). The measurement of observer agreement for categorical data. Biometrics, 1, 159-174.

Mintz, J., Auerbach, A.H., Luborsky, L. \& Johnson, M. (1973). Patient's, therapist's and observers' views of psychotherapy: A 'Rashomon' experience or a reasonable consensus? British Journal of Medical Psychology, 46(1), 83-89. 
Olivero, G., Bane, K.D. \& Kopelman, R.E. (1997). Executive coaching as a transfer of training tool: Effects on productivity in a public agency. Public Personnel Management, 26, 461-469.

Parsloe, E. \& Wray, M. (2000). Coaching and mentoring. London: Kogan Page.

Peterson, D.B. (1993). Skill learning and behavior change in an individually tailored management coaching and training programme (Doctoral Dissertation, University of Minnesota). Dissertation Abstracts International, 54(3), 1707-1708.

Rice, L.N. \& Greenberg, L.S. (Eds.) (1984). Patterns of change: Intensive analysis of psychotherapeutic process. New York: Guilford Press.

Schein, E.H. (1985). Organisational culture and leadership. San Francisco, CA: Jossey-Bass.

Schlosser, B., Steinbrenner, D., Kumata, E. \& Hunt, J. (2006). The coaching impact study: Measuring the value of executive coaching. The International Journal of Coaching in Organizations, 4(3), 8-26.

Sherman, S. \& Freas, A. (2004). The wild west of executive coaching. Boston, MA: Harvard Business Review.

Smither, J.W., London, M., Flaw, R., Vargas, Y. \& Kucine, I. (2003). Can working with an executive coach improve multisource feedback ratings over time? A quasi-experimental field study. Personnel Psychology, 56, 23-44.

Spence, G.B. \& Grant, A.M. (2005). Individual and group life-coaching: Initial findings from a randomised, controlled trial. In M. Cavanagh, A.M. Grant \& T. Kemp, Evidence-based coaching Vol. 1: Theory, research and practice from the behavioural sciences (pp.143-158). Bowen Hills, Queensland: Australian Academic Press.
Strauss, A. \& Corbin, J. (1990). Basics of qualitative research: Grounded theory procedures and techniques. Newbury Park, CA: Sage.

Sue-Chan, S. \& Latham, G.P. (2004). The relative effectiveness of external, peer, and self-coaches. Applied Psychology: An International Review, 53(2), 260-278.

Thach, E.C. (2002). The impact of executive coaching and $360^{\circ}$ feedback on leadership effectiveness. Leadership $\mathcal{E}$ Organization Development Journal, 23(4), 205-214.

Wasylyshyn, K.M. (2003). Executive coaching: An outcome study. Consulting Psychology Journal: Practice and Research, 55, 94-106.

Wasylyshyn, K.M., Gronsky, B. \& Haas, J.W. (2006). Tigers, stripes, and behavior change: Survey results of a commissioned coaching program. Consulting Psychology Journal: Practice and Research, 2(58), 65-81.

Weiss, I., Rabinowitz, J. \& Spiro, S. (1996). Agreement between therapists and clients in evaluating therapy and its outcomes: Literature review. Administration and Policy in Mental Health and Mental Health Services Research, 23(6), 493-511.

Zeus, P. \& Skiffington, S. (2002). The complete guide to coaching at work. New York: McGraw-Hill. 


\section{Appendix A}

Paired sample $t$-tests comparing code 1 to other codes in coding scheme 1 ; Hypothesis 1 .

\begin{tabular}{|l|c|c|c|c|}
\hline Pair & mean & $t$ & $d f$ & $p$ \\
\hline $\begin{array}{l}\text { Code 1 } \\
\text { Code 3 }\end{array}$ & $\begin{array}{l}.40 \\
.21\end{array}$ & 2.52 & 97 & .014 \\
\hline $\begin{array}{l}\text { Code 1 } \\
\text { Code 4 }\end{array}$ & $\begin{array}{l}.40 \\
.09\end{array}$ & 4.79 & 97 & .000 \\
\hline $\begin{array}{l}\text { Code 1 } \\
\text { Code 5 }\end{array}$ & $\begin{array}{l}.40 \\
.32\end{array}$ & 1.13 & 97 & .260 \\
\hline $\begin{array}{l}\text { Code 1 } \\
\text { Code 6 }\end{array}$ & $\begin{array}{l}.40 \\
.24\end{array}$ & 2.02 & 97 & .046 \\
\hline $\begin{array}{l}\text { Code 1 } \\
\text { Code 7 }\end{array}$ & $\begin{array}{l}.40 \\
.09\end{array}$ & 5.06 & 97 & .000 \\
\hline $\begin{array}{l}\text { Code 1 } \\
\text { Code 8 }\end{array}$ & $\begin{array}{l}.40 \\
.04\end{array}$ & 6.31 & 97 & .000 \\
\hline $\begin{array}{l}\text { Code 1 } \\
\text { Code 9 }\end{array}$ & $\begin{array}{l}.40 \\
.09\end{array}$ & 5.01 & 97 & .000 \\
\hline $\begin{array}{l}\text { Code 1 } \\
\text { Code 10 }\end{array}$ & $\begin{array}{l}.40 \\
.08\end{array}$ & 5.20 & 97 & .000 \\
\hline $\begin{array}{l}\text { Code 1 } \\
\text { Code 11 }\end{array}$ & $\begin{array}{l}.40 \\
.10\end{array}$ & 4.78 & 97 & .000 \\
\hline $\begin{array}{l}\text { Code 1 } \\
\text { Code 12 }\end{array}$ & $\begin{array}{l}.40 \\
.03\end{array}$ & 6.92 & 97 & .000 \\
\hline
\end{tabular}

Paired sample $t$-tests comparing code 2 to other codes in coding scheme 1 ; Hypothesis 1.

\begin{tabular}{|l|c|c|c|c|}
\hline Pair & mean & $t$ & $d f$ & $p$ \\
\hline $\begin{array}{l}\text { Code 2 } \\
\text { Code 3 }\end{array}$ & $\begin{array}{l}.41 \\
.21\end{array}$ & 2.69 & 97 & .008 \\
\hline $\begin{array}{l}\text { Code 2 } \\
\text { Code 4 }\end{array}$ & $\begin{array}{l}.41 \\
.09\end{array}$ & 5.06 & 97 & .000 \\
\hline $\begin{array}{l}\text { Code 2 } \\
\text { Code 5 }\end{array}$ & $\begin{array}{l}.41 \\
.32\end{array}$ & 1.24 & 97 & .218 \\
\hline $\begin{array}{l}\text { Code 2 } \\
\text { Code 6 }\end{array}$ & $\begin{array}{l}.41 \\
.24\end{array}$ & 2.36 & 97 & .020 \\
\hline $\begin{array}{l}\text { Code 2 } \\
\text { Code 7 }\end{array}$ & $\begin{array}{l}.41 \\
.09\end{array}$ & 5.20 & 97 & .000 \\
\hline $\begin{array}{l}\text { Code 2 } \\
\text { Code 8 }\end{array}$ & $\begin{array}{l}.41 \\
.04\end{array}$ & 6.46 & 97 & .000 \\
\hline $\begin{array}{l}\text { Code 2 } \\
\text { Code 9 }\end{array}$ & $\begin{array}{l}.41 \\
.09\end{array}$ & 5.20 & 97 & .000 \\
\hline $\begin{array}{l}\text { Code 2 } \\
\text { Code 10 }\end{array}$ & $\begin{array}{l}.41 \\
.08\end{array}$ & 5.20 & 97 & .000 \\
\hline $\begin{array}{l}\text { Code 2 } \\
\text { Code 11 }\end{array}$ & $\begin{array}{l}.41 \\
.10\end{array}$ & 5.01 & 97 & .000 \\
\hline $\begin{array}{l}\text { Code 2 } \\
\text { Code 12 }\end{array}$ & $\begin{array}{l}.41 \\
.03\end{array}$ & 6.83 & 97 & .000 \\
\hline
\end{tabular}




\section{Appendix B}

Paired sample $t$-tests comparing code 3 to other codes in coding scheme 1; Hypothesis 2.

\begin{tabular}{|l|c|c|c|c|}
\hline Pair & mean & $t$ & $d f$ & $p$ \\
\hline $\begin{array}{l}\text { Code 3 } \\
\text { Code 1 }\end{array}$ & $\begin{array}{l}.44 \\
.20\end{array}$ & 3.13 & 78 & .002 \\
\hline $\begin{array}{l}\text { Code 3 } \\
\text { Code 2 }\end{array}$ & $\begin{array}{l}.44 \\
.38\end{array}$ & .74 & 78 & .460 \\
\hline $\begin{array}{l}\text { Code 3 } \\
\text { Code 7 }\end{array}$ & $\begin{array}{l}.44 \\
.14\end{array}$ & 4.30 & 78 & .000 \\
\hline $\begin{array}{l}\text { Code 3 } \\
\text { Code 8 }\end{array}$ & $\begin{array}{l}.44 \\
.03\end{array}$ & 7.12 & 78 & .000 \\
\hline $\begin{array}{l}\text { Code 3 } \\
\text { Code 9 }\end{array}$ & $\begin{array}{l}.44 \\
.01\end{array}$ & 7.67 & 78 & .000 \\
\hline $\begin{array}{l}\text { Code 3 } \\
\text { Code 10 }\end{array}$ & $\begin{array}{l}.44 \\
.00\end{array}$ & 7.88 & 78 & .000 \\
\hline $\begin{array}{l}\text { Code 3 } \\
\text { Code 11 }\end{array}$ & $\begin{array}{l}.44 \\
.00\end{array}$ & 7.88 & 78 & .000 \\
\hline $\begin{array}{l}\text { Code 3 } \\
\text { Code 12 }\end{array}$ & $\begin{array}{l}.44 \\
.00\end{array}$ & 7.88 & 78 & .000 \\
\hline
\end{tabular}

Paired sample $t$-tests comparing code 6 to other codes in coding scheme 1; Hypothesis 2.

\begin{tabular}{|l|c|c|c|c|}
\hline Pair & mean & $t$ & $d f$ & $p$ \\
\hline $\begin{array}{l}\text { Code 6 } \\
\text { Code 1 }\end{array}$ & $\begin{array}{l}.75 \\
.20\end{array}$ & 7.37 & 79 & .000 \\
\hline $\begin{array}{l}\text { Code 6 } \\
\text { Code 2 }\end{array}$ & $\begin{array}{l}.75 \\
.38\end{array}$ & 4.54 & 79 & .000 \\
\hline $\begin{array}{l}\text { Code 6 } \\
\text { Code } 7\end{array}$ & $\begin{array}{l}.75 \\
.14\end{array}$ & 8.59 & 79 & .000 \\
\hline $\begin{array}{l}\text { Code 6 } \\
\text { Code } 8\end{array}$ & $\begin{array}{l}.75 \\
.03\end{array}$ & 14.22 & 79 & .000 \\
\hline $\begin{array}{l}\text { Code 6 } \\
\text { Code 9 }\end{array}$ & $\begin{array}{l}.75 \\
.01\end{array}$ & 13.81 & 79 & .000 \\
\hline $\begin{array}{l}\text { Code 6 } \\
\text { Code 10 }\end{array}$ & $\begin{array}{l}.75 \\
.00\end{array}$ & 15.17 & 79 & .000 \\
\hline $\begin{array}{l}\text { Code 6 } \\
\text { Code 11 }\end{array}$ & $\begin{array}{l}.75 \\
.00\end{array}$ & 15.17 & 79 & .000 \\
\hline $\begin{array}{l}\text { Code 6 } \\
\text { Code 12 }\end{array}$ & $\begin{array}{l}.75 \\
.00\end{array}$ & 15.17 & 79 & .000 \\
\hline
\end{tabular}




\section{Appendix C}

Paired sample $t$-tests comparing code 1 to other codes in coding scheme 2;

Hypothesis 3.

\begin{tabular}{|l|c|c|c|c|}
\hline Pair & mean & $t$ & $d f$ & $p$ \\
\hline $\begin{array}{l}\text { Code 1 } \\
\text { Code 6 }\end{array}$ & $\begin{array}{l}.18 \\
.05\end{array}$ & 2.43 & 78 & .017 \\
\hline $\begin{array}{l}\text { Code 1 } \\
\text { Code 7 }\end{array}$ & $\begin{array}{l}.18 \\
.15\end{array}$ & .39 & 78 & .698 \\
\hline $\begin{array}{l}\text { Code 1 } \\
\text { Code 8 }\end{array}$ & $\begin{array}{l}.18 \\
.23\end{array}$ & -.75 & 78 & .453 \\
\hline $\begin{array}{l}\text { Code 1 } \\
\text { Code 9 }\end{array}$ & $\begin{array}{l}.18 \\
.30\end{array}$ & -1.79 & 78 & .077 \\
\hline $\begin{array}{l}\text { Code 1 } \\
\text { Code 10 }\end{array}$ & $\begin{array}{l}.18 \\
.11\end{array}$ & 1.04 & 78 & .300 \\
\hline $\begin{array}{l}\text { Code 1 } \\
\text { Code 11 }\end{array}$ & .18 & 1.04 & 78 & .300 \\
\hline
\end{tabular}

Paired sample $t$-tests comparing code 3 to other codes in coding scheme 2; Hypothesis 3.

\begin{tabular}{|c|c|c|c|c|}
\hline Pair & mean & $t$ & $d f$ & $p$ \\
\hline $\begin{array}{l}\text { Code } 3 \\
\text { Code } 6\end{array}$ & $\begin{array}{l}.06 \\
.05\end{array}$ & .38 & 78 & .71 \\
\hline $\begin{array}{l}\text { Code } 3 \\
\text { Code } 7\end{array}$ & $\begin{array}{l}.06 \\
.15\end{array}$ & -1.83 & 78 & .070 \\
\hline $\begin{array}{l}\text { Code } 3 \\
\text { Code } 8\end{array}$ & $\begin{array}{l}.06 \\
.23\end{array}$ & -2.97 & 78 & .004 \\
\hline $\begin{array}{l}\text { Code } 3 \\
\text { Code } 9\end{array}$ & $\begin{array}{l}.06 \\
.30\end{array}$ & -3.99 & 78 & .000 \\
\hline $\begin{array}{l}\text { Code } 3 \\
\text { Code } 10\end{array}$ & $\begin{array}{l}.06 \\
.11\end{array}$ & -1.07 & 78 & .288 \\
\hline $\begin{array}{l}\text { Code } 3 \\
\text { Code } 11\end{array}$ & $\begin{array}{l}.06 \\
.11\end{array}$ & -1.16 & 78 & .251 \\
\hline
\end{tabular}

Paired sample $t$-tests comparing code 2 to other codes in coding scheme 2; Hypothesis 3.

\begin{tabular}{|l|c|c|c|c|}
\hline Pair & mean & $t$ & $d f$ & $p$ \\
\hline $\begin{array}{l}\text { Code 2 } \\
\text { Code 6 }\end{array}$ & $\begin{array}{l}.24 \\
.05\end{array}$ & 3.32 & 78 & .001 \\
\hline $\begin{array}{l}\text { Code 2 } \\
\text { Code 7 }\end{array}$ & $\begin{array}{l}.24 \\
.15\end{array}$ & 1.35 & 78 & .180 \\
\hline $\begin{array}{l}\text { Code 2 } \\
\text { Code 8 }\end{array}$ & $\begin{array}{l}.24 \\
.23\end{array}$ & .17 & 78 & .863 \\
\hline $\begin{array}{l}\text { Code 2 } \\
\text { Code 9 }\end{array}$ & $\begin{array}{l}.24 \\
.30\end{array}$ & -.84 & 78 & .401 \\
\hline $\begin{array}{l}\text { Code 2 } \\
\text { Code 10 }\end{array}$ & $\begin{array}{l}.24 \\
.11\end{array}$ & 2.00 & 78 & .049 \\
\hline $\begin{array}{l}\text { Code 2 } \\
\text { Code 11 }\end{array}$ & $\begin{array}{l}.24 \\
.11\end{array}$ & 2.00 & 78 & .049 \\
\hline
\end{tabular}

Paired sample $t$-tests comparing code 4 to other codes in coding scheme 2; Hypothesis 3.

\begin{tabular}{|l|c|c|c|c|}
\hline Pair & mean & $t$ & $d f$ & $p$ \\
\hline $\begin{array}{l}\text { Code 4 } \\
\text { Code } 6\end{array}$ & $\begin{array}{l}.14 \\
.05\end{array}$ & 1.98 & 78 & .052 \\
\hline $\begin{array}{l}\text { Code 4 } \\
\text { Code } 7\end{array}$ & $\begin{array}{l}.14 \\
.15\end{array}$ & -.24 & 78 & .810 \\
\hline $\begin{array}{l}\text { Code 4 } \\
\text { Code } 8\end{array}$ & $\begin{array}{l}.14 \\
.23\end{array}$ & -1.54 & 78 & .127 \\
\hline $\begin{array}{l}\text { Code 4 } \\
\text { Code } 9\end{array}$ & .14 & -2.40 & 78 & .019 \\
\hline $\begin{array}{l}\text { Code 4 } \\
\text { Code 10 }\end{array}$ & .14 & .50 & 78 & .620 \\
\hline $\begin{array}{l}\text { Code 4 } \\
\text { Code 11 }\end{array}$ & .14 & .11 & 78 & .658 \\
\hline
\end{tabular}


Paired sample $t$-tests comparing code 5

to other codes in coding scheme 2;

Hypothesis 3.

\begin{tabular}{|l|c|c|c|c|}
\hline Pair & mean & $t$ & $d f$ & $p$ \\
\hline $\begin{array}{l}\text { Code 5 } \\
\text { Code } 6\end{array}$ & $\begin{array}{l}.15 \\
.05\end{array}$ & 2.19 & 78 & .032 \\
\hline $\begin{array}{l}\text { Code 5 } \\
\text { Code } 7\end{array}$ & $\begin{array}{l}.15 \\
.15\end{array}$ & .00 & 78 & 1.00 \\
\hline $\begin{array}{l}\text { Code 5 } \\
\text { Code } 8\end{array}$ & $\begin{array}{l}.15 \\
.23\end{array}$ & -1.28 & 78 & .203 \\
\hline $\begin{array}{l}\text { Code 5 } \\
\text { Code } 9\end{array}$ & $\begin{array}{l}.15 \\
.30\end{array}$ & -2.24 & 78 & .028 \\
\hline $\begin{array}{l}\text { Code 5 } \\
\text { Code 10 }\end{array}$ & $\begin{array}{l}.15 \\
.11\end{array}$ & .65 & 78 & .516 \\
\hline $\begin{array}{l}\text { Code 5 } \\
\text { Code } 11\end{array}$ & .15 & .69 & 78 & .495 \\
\hline
\end{tabular}

